\title{
Capsule Commentary on Strong et al., Work-Life Balance in Academic Medicine: Narratives of Physician-Researchers and Their Mentors
}

\author{
Bubu Banini, MD PhD \\ Department of Internal Medicine, Sound Shore Medical Center of Westchester, New Rochelle, NY, USA.
}

J Gen Intern Med 28(12):1646

DOI: $10.1007 / \mathrm{s} 11606-013-2557-3$

(c) Society of General Internal Medicine 2013

$\mathrm{T}$ he ability to balance professional and family responsibilities remains a challenge for most working adults. This is even more so for physicians, who experience a higher level of burnout and work-life balance dissatisfaction compared to their non-medical counterparts. ${ }^{1}$ Dissatisfaction with work-life balance is highest for physicians at the forefront of medical care, including family medicine, general internal medicine and emergency medicine. ${ }^{1}$ As one may expect, the subset of physicians who combine clinical responsibilities with research activities experience an even greater level of work-life balance issues.

Strong et al. ${ }^{2}$ qualitatively assessed work-life balance among physicians in academic medicine through telephone interviews of 100 physician recipients of NIH K08 or K23 awards and 28 of their mentors. Interview participants were asked about family structure, effects of family and personal demands on careers success as well as institutional policies influencing work-life balance. Their results showed that while the new generation of academic physicians seems to be more cognizant of maintaining work-life balance than the "older," work-life balance remains challenging due to work demands and inadequate job flexibility. Even when supervisors offer flexible scheduling and time off, many female academic physicians are hesitant to make use of these offers due to societal and gender stereotypes. They do not want to be perceived as being on the "mommy track".

It is clearly not enough for employers to simply offer flexibility in work scheduling or time off; a concerted effort to de-stigmatize these opportunities and encourage employees to utilize them is necessary to overcome societal beliefs and expectations that have been entrenched through generations. Furthermore, physician researchers who achieve work-life balance need to take an active role in mentoring the younger generation. Physician peer mentoring has been shown to improve both academic productivity and personal life. ${ }^{3,4}$ In addition, the individual physician must take the initiative to plan ahead and communicate effectively ${ }^{5}$ with those in the professional as well as the personal arena. Attaining the elusive balance between work and life is important and requires continued effort from both institutions and individuals.

Conflict of Interest: The author declares no conflict of interest.

Corresponding Author: Bubu Banini, MD PhD; Department of Internal Medicine, Sound Shore Medical Center of Westchester, New Rochelle, NY 10801, USA (e-mail: bububanini@yahoo.com).

\section{REFERENCES}

1. Shanafelt TD, Boone S, Tan L, Dyrbye LN, Sotile W, Satele D, West CP, Sloan J, Oreskovich MR. Burnout and satisfaction with work-life balance among US physicians relative to the general US population. Arch Intern Med. 2012;172(18):1377-85.

2. Strong EA, DeCastro R, Sambuco D, Stewart A, Ubel PA, Griffith KA, Jagsi R. Work-Life Balance in Academic Medicine: Narratives of Physician-Researchers and Their Mentors. J Gen Inten Med. 2013. doi:10.1007/s11606-013-2521-2.

3. Varkey P, Jatoi A, Williams A, Mayer A, Ko M, Files J, Blair J, Hayes S. The positive impact of a facilitated peer mentoring program on academic skills of women faculty. BMC Med Educ. 2012;12:14.

4. De Ridder D. How to add more "family" to the work-life-balance? - family friendliness in medical under- and postgraduate studies and the workplace. GMS Z Med Ausbild. 2012;29(2):Doc22.

5. Kirby E, Krone K. The Policy Exists but You Can't Really Use it: Communication and the Structuration of Work-Family Policies. Journal of Applied Communication Research. 2002;30:50-77. 